\title{
Telomere Biology and Human Phenotype
}

\author{
Kara J. Turner ${ }^{1}$, Vimal Vasu ${ }^{1,2}$ (D) and Darren K. Griffin ${ }^{1, *(D)}$ \\ 1 University of Kent, School of Biosciences, Giles Lane, Canterbury, Kent, CT2-7NJ, UK; \\ k.j.turner-24@kent.ac.uk (K.J.T.); vimal.vasu@nhs.net (V.V.) \\ 2 Department of Child Health, East Kent Hospitals University Foundation NHS Trust, \\ William Harvey Hospital, Ashford, Kent, TN24-0LZ, UK \\ * Correspondence: d.k.griffin@kent.ac.uk; Tel.: +44-(0)1227-823-022
}

Received: 24 December 2018; Accepted: 16 January 2019; Published: 19 January 2019

\begin{abstract}
Telomeres are nucleoprotein structures that cap the end of each chromosome arm and function to maintain genome stability. The length of telomeres is known to shorten with each cell division and it is well-established that telomere attrition is related to replicative capacity in vitro. Moreover, telomere loss is also correlated with the process of aging in vivo. In this review, we discuss the mechanisms that lead to telomere shortening and summarise telomere homeostasis in humans throughout a lifetime. In addition, we discuss the available evidence that shows that telomere shortening is related to human aging and the onset of age-related disease.
\end{abstract}

Keywords: telomeres; telomere length; aging; senescence

\section{Introduction: Structure, Function and Maintenance of the Telomere}

Telomeres are nucleoprotein structures found at the end of each chromosome arm that function to maintain genome stability. In all mammals, telomeres are formed of a highly conserved, hexameric (TTAGGG) tandem repeat DNA sequence. This is organised into a looped structure called a T-loop and associated with specialised proteins including, among others, those that make up the Shelterin complex [1-3]. The looped structure (Figure 1) is formed via nucleolytic activity at the extreme termini of telomeric DNA to produce a single stranded G-rich overhang. This loops back and invades the double stranded telomere tract $[4,5]$, ensuring that loose DNA ends are housed internally within the nucleoprotein structure.

There are many proteins associated with the telomere that, combined, make up the telosome. Some are involved in DNA damage response mechanisms, for example DNA protein kinase (DNA-PK), p53, polyadenosine diphosphate ribose polymerase (PARP), Tankyrase 1 and 2, Excision repair cross-complementing associated with xeroderma pigmentosum group $\mathrm{F}$ (ERCC/XPF) radiation 51 (RAD51), werner (WRN) and bloom (BLM) [6,7]. Others are involved in nuclear organization such as lamin associated proteins (LAPs) [8,9] and silent information regulator (Sir) proteins, which are also involved in epistatic control of telomere length [10]. The presence and action of these proteins at the telomere sequence is largely governed by proteins that make up the Shelterin complex. This complex is made up of a collection of six specialized proteins that associate with the telomere structure to form a fully functional capping structure. These proteins and their characteristics are outlined in further detail in Table 1. 

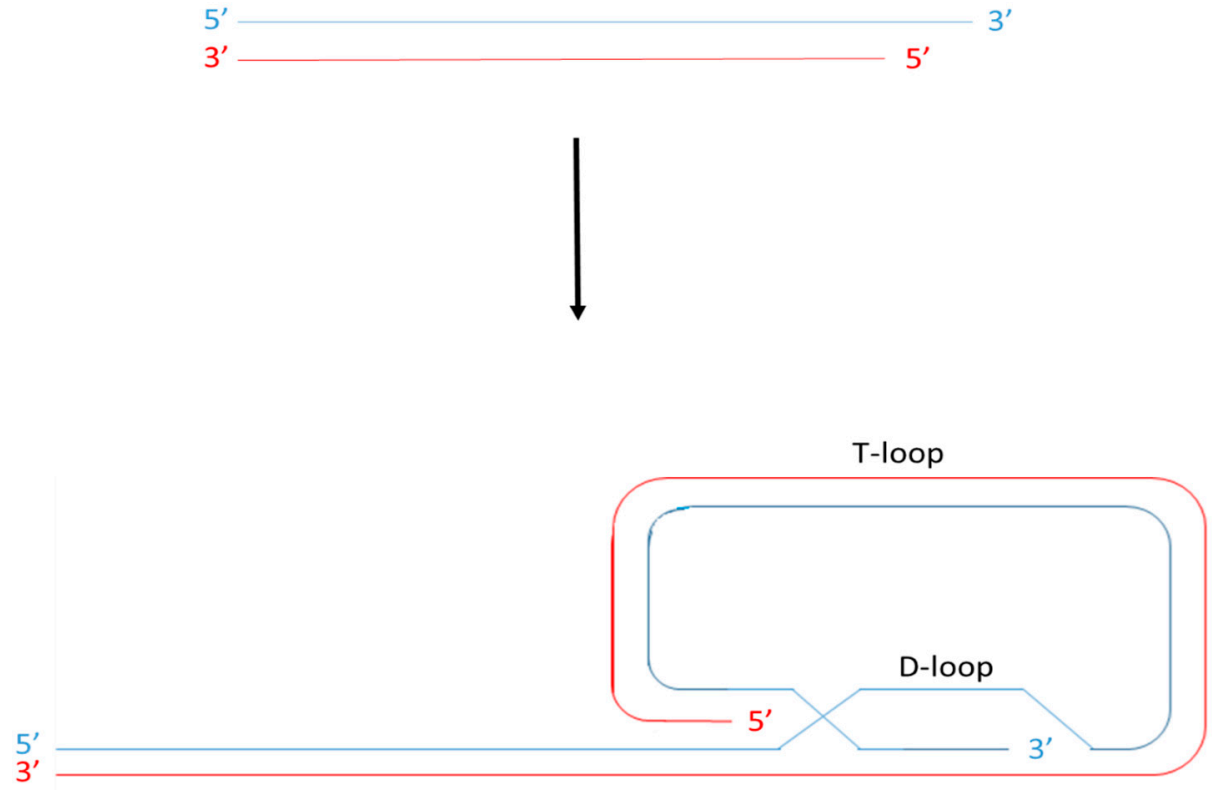

Figure 1. The T-loop and the D-loop. The $3^{\prime}$ end of the G rich strand (blue) protrudes as a single stranded extension of the telomere. This G-strand overhang loops back to form a T-loop and invades the $5^{\prime}$ double stranded telomeric duplex, forming a D-loop.

Table 1. The Shelterin complex: Characterisation of the proteins that make up the Shelterin complex $[3,11,12]$.

\begin{tabular}{|c|c|c|}
\hline Protein Name & Interactions & Function \\
\hline $\begin{array}{l}\text { Telomere repeat binding factor } 1 \\
\text { (TERF1 also known as TRF1) }\end{array}$ & $\begin{array}{l}\text { Direct interaction with double } \\
\text { stranded TTAGGG repeats }\end{array}$ & Regulation of telomere length \\
\hline $\begin{array}{l}\text { Telomere repeat binding factor } 2 \\
\text { (TERF2 also known as TRF2) }\end{array}$ & $\begin{array}{l}\text { Direct interaction with double } \\
\text { stranded TTAGGG repeats }\end{array}$ & $\begin{array}{l}\text { Stabilisation of the T-loop and } \\
\text { regulation of telomere length }\end{array}$ \\
\hline $\begin{array}{l}\text { TERF1 interacting nuclear factor } 2 \\
\text { (TINF2 also known as TIN2) }\end{array}$ & $\begin{array}{c}\text { Associates directly with TERF1, } \\
\text { TERF2 and ACD and indirectly } \\
\text { with POT1 }\end{array}$ & $\begin{array}{l}\text { Tethering of ACD and POT1 to } \\
\text { TERF1 and TERF2 and tethering } \\
\text { TERF1 to TERF2, which } \\
\text { stabilises the association of } \\
\text { TERF2 with the telomere. Also } \\
\text { regulates telomere length }\end{array}$ \\
\hline Protection of Telomeres 1 (POT1) & $\begin{array}{l}\text { Direct interaction with single } \\
\text { stranded telomere overhang }\end{array}$ & $\begin{array}{l}\text { Inhibition of DNA damage } \\
\text { response and regulation of } \\
\text { telomere length }\end{array}$ \\
\hline $\begin{array}{l}\text { Shelterin complex subunit and } \\
\text { telomerase recruitment factor } \\
\text { (ACD, also known as TPP1) }\end{array}$ & Interaction with TINF2 and POT1 & $\begin{array}{l}\text { Enhances POT1 binding to } \\
\text { single stranded telomere DNA } \\
\text { and regulates telomere length in } \\
\text { combination with POT1 }\end{array}$ \\
\hline $\begin{array}{l}\text { TERF2 interacting protein } \\
\text { (TERF2IP also known as RAP1) }\end{array}$ & Associates with TERF2 & Telomere length regulation \\
\hline
\end{tabular}

Interactions between members of the Shelterin complex and the telomere DNA sequence stabilise the telomere structure and regulate access of proteins involved in DNA repair and lengthening [3,11,13]. Collectively therefore, this specialised nucleoprotein structure functions to form a cap at the chromosome ends, serving two main functions: Firstly it shields the ends of chromosome arms from inappropriate DNA repair mechanisms, which might otherwise recognise loose DNA strands as a 
double strand break and result in chromosome fusion events. Secondly, this capping structure prevents the degradation of genes near the end of chromosome arms as a result of incomplete DNA replication.

During DNA replication, DNA polymerase may only synthesise new DNA in the $5^{\prime}$ to $3^{\prime}$ direction with the aid of RNA primers that are formed by the enzyme primase. These primers anneal to the template strands, providing a free $3^{\prime} \mathrm{OH}$ group for the addition of free nucleotides. Since the action of polymerase proceeds in the same direction as the progression of the replication fork, the synthesis of new DNA in the $5^{\prime}$ to $3^{\prime}$ direction requires only one primer and is continuous [14]. However, synthesis of a new $3^{\prime}$ to $5^{\prime}$ DNA strand progresses against the direction of the replication fork. Therefore synthesis of this new strand requires the annealing of multiple RNA primers which are elongated into short Okazaki fragments and subsequently ligated to form the new DNA strand [15]. Consequently, a length of DNA at least the size of the RNA primer is lost at the $5^{\prime}$ end of the lagging strand when the final RNA primer is removed following replication [16]. In reality however, a much larger amount of DNA is lost following replication as a consequence of priming failure [14] and as a consequence of the complex nature of the telomere structure itself. The association of telomere sequences with the Shelterin complex leads to replication fork stalling [17] and the presence of G-quadruplexes, which are an essential feature in the formation of the t-loop, results in replication fork slippage [5]. Furthermore, the synthesis of DNA via polymerase action produces blunt ends. In order to form a T-loop, nucleolytic activity is required to produce a single stranded overhang (Figure 1). Thus, there are several mechanisms that result in telomere attrition following replication in proliferating cells and it is thought that the presence of the telomere sequence acts as a 'buffering system' to prevent the loss of crucial DNA. Eventually however, this buffering system is lost and it is widely accepted that, as a consequence of this, the cell loses its ability to proliferate and reaches its so-called replicative capacity.

Once telomeres have shortened beyond a critical level, the proteins that form the Shelterin complex are unable to associate with the telomeric sequence and can no longer perform their role in capping the end of the chromosome. Therefore, a major limiting factor in the function of the telomere is its length. This represents a problem in cells that are highly mitotically active, such as stem cells that differentiate in order to generate new tissue or replace damaged cells. In these cells, it is important that telomere length is maintained to ensure prolonged replicative capacity and this is achieved via two primary mechanisms: The action of a specialised enzyme called telomerase or homologous recombination mediated alternative lengthening of telomeres (ALT). Telomerase is a ribonucleoprotein complex, made up of a telomerase reverse transcriptase (TERT) catalytic subunit that synthesises new telomeric repeats by copying its telomerase RNA component (TERC) [18]. In most cell types, its action is inhibited by the competitive binding of telomeric repeat containing RNA (TERRA) (which is transcribed from sub-telomeric and telomeric DNA sequences) to TERC and via contact with TERT [19,20]. Several cell types including stem cells are able to express telomerase however and in cells that do not (or where telomerase is repressed) homologous recombination based ALT may extend telomere length. In this scenario it is thought that the $5^{\prime}$ overhang belonging to the telomere of one chromatid may invade the T-loop of the homologous chromatid. This structure resembles a replication fork that is recognised by DNA polymerase and is subsequently extended [21].

Despite the presence of these elongation mechanisms, telomere shortening is still observed following proliferation in most stem cells (with the exception of embryonic stem cells). This is because telomere elongation mechanisms are increasingly reduced during differentiation and therefore they become insufficient to completely eradicate telomere loss. In the majority of differentiated somatic cells (except for lymphocytes), telomerase is not expressed at all and therefore in these cells, telomere length declines with each division [22].

\section{Telomere Length and Replicative Capacity}

The finite replicative capacity of somatic cells has been recognised since Leonard Hayflick's work in the 1960s [23]. However, its association with the 'end replication problem' was not discovered until the 1970s and it was a further twenty years before telomere shortening was formally associated with 
passage number and replicative capacity in vitro [24-26]. Since then, an array of studies have shown that telomere length is correlated with donor age in a variety of somatic cell types, generally declining as a function of chronological age [27-34].

Furthermore, the contribution of telomere attrition to the process of aging has been well characterised and it is now generally accepted that when telomere length becomes critically short, the ability to support the Shelterin complex is lost. In turn, the inhibitory action of the Shelterin complex on DNA damage response pathways is released and the cell cycle leaves G1 and enters G0 [35]. This is initiated by the ataxia telangiectasia mutated (ATM) or the ataxia telangiectasia and radiation 3 (RAD3) related protein (ATR) pathway. Both of these lead to the phosphorylation of p53, expression of p21 and inhibition of cyclin dependent kinases that would otherwise enable progression through the cell cycle [36,37]. Upon leaving the cell cycle, the cell either enters senescence (defined as the irreversible cessation of division) or apoptosis, (defined as programmed cell death). The exact mechanisms that dictate the committal to senescence or apoptosis are poorly understood [38] and the characteristics of each scenario are quite different. However, the outcome (inability of the cell to continue division) is the same.

The consequence of an accumulation of senescent cells is two-fold: Firstly, senescence leads to a reduction in the number of mitotically active cells in a given tissue, limiting the potential for growth and repair. Secondly their accumulation results in the release of proteases, growth factors and inflammatory cytokines which act on non-senescent neighbouring cells. Normally, this initiates clearance of senescent cells by the immune system. However, as the immune system ages its ability to clear senescent cells becomes impaired $[37,38]$. Ultimately therefore, it is thought that the accumulation of senescent cells as a result of telomere attrition drives the process of tissue and organismal aging. In order to test this hypothesis, a multitude of studies have measured telomere length in vivo in relation to chronological age [30-32,34]. Moreover, a variety of studies have investigated the relationship between telomere length and age-related disease [39-41].

\section{Telomere Homeostasis Throughout a Life-Time}

As male and female gametes fuse during the process of fertilisation, telomere length must be reset in order for the offspring to have sufficient telomeric reserve to develop and fulfil a healthy lifespan. Following fertilisation, telomere length declines in the cleavage stage embryo in comparison to the oocyte and declines further still at the morula stage [42] in line with a decline in telomerase activity during this time [43]. At the blastocyst stage however, telomerase activity is markedly increased and telomeres are lengthened [42,43]. At present, information regarding telomere dynamics in the earliest weeks of gestation are lacking except for a few notable observations. Cheng and colleagues showed that, between weeks six and seven of gestation, telomere length rapidly declines, however this is slowed between weeks eight and eleven and then remains constant thereafter (that is, telomere length in foetuses above eleven weeks' gestation was not different to that of full term babies) [44]. This finding is supported by others whom concluded that telomere length is not associated with gestational age in foetuses between 15 and 19 weeks' gestation [45] and that, although telomere length may fluctuate between 23 and 36 weeks' gestation, overall telomere length is either increased or no detectable change is observed [46]. Furthermore, telomere length appears to be synchronous among different tissues during foetal life [45] and is maintained by telomerase activity in utero [44,47,48].

At the time of birth, many have shown that telomere length is highly variable [49-52], a finding consistent with the highly variable telomere length observed in human embryos [42] and foetuses $[45,46]$. Furthermore, telomere length in newborns appears to be associated with parental telomere lengths, though controversy exists as to the relative influence of the mother $[53,54]$ and the father $[55,56]$. Interestingly, telomere length appears to maintain synchrony between tissues at the time of birth and telomere length appears similar between male and female babies [49,52]. This is in contrast to observations in adults which indicate that while telomere lengths in different tissues may be correlated, they are highly variable $[57,58]$ and that telomere length is longer in women than in men $[40,59,60]$. 
Following birth, telomere length begins to decline within the first weeks of postnatal life and interestingly, this pattern holds true for infants born preterm, indicating that foetal telomere length maintenance is specific to life in utero [50,51]. Moreover, it has been shown that the rate of telomere shortening is most pronounced in the early years of life following birth and that this rate of attrition declines in young adulthood and reduces further still in older individuals [29-32,34]. Despite the relatively earlier onset of telomere shortening in preterm infants in comparison to term born infants overall telomere length does not appear to be significantly shortened at term equivalent age [49] or in early childhood [61]. Interestingly however, a number of studies have highlighted that telomere attrition rate in adults is most prominent in those with higher telomere length at baseline $[59,62,63]$.

\section{Telomere Length in Relation to Demographic and Lifestyle Factors}

Evidence to support the hypothesis that telomere length is inversely correlated with chronological age is well-documented within the literature. However, it is important to note that in many studies the data appears to be somewhat scattered and the correlations between telomere length and chronological age may be less well-established than previously thought. In addition, telomere length has been shown to be highly variable among individuals of the same or similar age in all age ranges assessed. Alongside chronological aging, available evidence (summarised in Table 2) supports the notion that a wealth of genetic and environmental factors may modulate telomere length.

Table 2. Demographic factors affecting telomere length: An overview of current findings and references.

\begin{tabular}{|c|c|c|}
\hline Demographic Factors & General Observations & References \\
\hline Genetic factors & $\begin{array}{l}\text { Several twin studies have identified high heritability } \\
\text { of telomere length and many specific loci associated } \\
\text { with telomere length have been reported. }\end{array}$ & [64-67] \\
\hline Gender & $\begin{array}{l}\text { Longer telomeres are found in adult females } \\
\text { compared to males. This is thought to be due to } \\
\text { higher levels of oestrogen, which confers } \\
\text { anti-inflammatory as well as antioxidant properties } \\
\text { and is known to promote telomerase expression. }\end{array}$ & {$[60,68-70]$} \\
\hline Ethnicity & $\begin{array}{l}\text { Telomeres are slightly longer in white individuals } \\
\text { compared to black and Hispanic individuals. } \\
\text { However, this difference is often not statistically } \\
\text { significant unless also adjusted for other factors such } \\
\text { as age, sex, socio-economic background and lifestyle } \\
\text { factors (diet and smoking) }\end{array}$ & [71] \\
\hline Level of psychosocial stress & $\begin{array}{c}\text { Shortened telomeres are associated with high levels } \\
\text { of psychosocial stress as a result of increased } \\
\text { oxidative stress as well as reduced telomerase } \\
\text { activity. Telomere length is also inversely correlated } \\
\text { with major depressive disorder due to increased } \\
\text { inflammatory factors leading to increased } \\
\text { oxidative stress. }\end{array}$ & {$[72-74]$} \\
\hline Level of physical activity & $\begin{array}{l}\text { Longer telomeres have been found in those that } \\
\text { engage in higher levels of physical activity, which is } \\
\text { associated with improved physical and psychological } \\
\text { wellbeing. Thus it is possible that the effects of } \\
\text { physical activity on telomere length are influenced by } \\
\text { a positive effect on physical and mental well-being }\end{array}$ & [75-77] \\
\hline
\end{tabular}


Table 2. Cont.

\begin{tabular}{|c|c|c|}
\hline Demographic Factors & General Observations & References \\
\hline Obesity & $\begin{array}{l}\text { Telomeres are known to be shortened in obese } \\
\text { individuals. Obesity is associated with chronic } \\
\text { inflammation, increased reactive oxygen species } \\
\text { (ROS) production in adipose tissue and evidence of } \\
\text { increased systemic oxidative stress. Furthermore, } \\
\text { telomere length is correlated with body mass index } \\
\text { (BMI), with increased BMI resulting in higher blood } \\
\text { volume, stimulating increased proliferation of blood } \\
\text { cells and leading to telomere shortening. } \\
\text { Interestingly, weight loss is positively correlated with } \\
\text { telomere lengthening and those with shortest } \\
\text { telomere length at baseline benefit from the most } \\
\text { pronounced rate of telomere lengthening following } \\
\text { weight loss. A greater adherence to a Mediterranean } \\
\text { diet is also associated with longer telomeres. }\end{array}$ & [78-81] \\
\hline Smoking & $\begin{array}{c}\text { Telomere length is shorter in smokers and } \\
\text { ex-smokers compared to non-smokers and negatively } \\
\text { associated with the amount of cigarettes smoked } \\
\text { per year. }\end{array}$ & {$[78,82]$} \\
\hline Alcohol consumption & $\begin{array}{l}\text { Telomere length is negatively correlated with the } \\
\text { number of alcohol units consumed per day and is } \\
\text { shorter in alcohol abusers compared to controls. }\end{array}$ & [83] \\
\hline
\end{tabular}

\section{Telomere Length and Biological Aging}

The high inter-individual variability of telomere length means that, although it is convincingly associated with the finite replicative capacity of cells in vitro, its relationship with the process of biological aging in vivo is more difficult to unpick. Aging can be defined as the gradual decline in normal tissue and organ function over time as a consequence of an accumulation of senescent cells and a decline in the regenerative potential of stem cells [84,85]. This decline in tissue function can be thought of as normal 'wear and tear' that occurs over time and may be the sole cause or a contributing factor to the development of age-related diseases in combination with other inducers of cell senescence [84]. Such inducers might include endogenous factors; for example mitochondrial dysfunction [86,87] and inflammation [88] or exogenous factors; such as cigarette smoking, high fat diet, chemotherapy, radiation and other environmental or lifestyle factors $[84,89]$. These factors are strongly linked with the production of reactive oxygen species (ROS), which are known to induce cellular senescence and moreover [89], it is thought that the G-rich telomere repeat sequence is particularly susceptible to oxidative damage [90]. Since telomere attrition is an initiator of cell senescence in vitro, a variety of studies have sought to investigate the relationship between telomere shortening and age-related diseases. These commonly occur during the process of normal aging but in rare examples, may occur in the context of premature aging disorders.

\subsection{Telomere Biology and Premature Aging Disorders}

Premature aging disorders result in characteristic symptoms normally associated with old age, such as hair greying, hair loss, neurological degeneration, loss of subcutaneous fat, skin atrophy and cancers. In all cases, genetic mutations lead to dysfunctional proteins that are involved in DNA damage response and/or DNA damage repair pathways, telosome structure or telomere length regulation. As a result, depending on the affected pathway, telomere length may be shortened in these individuals or the rate of telomere attrition may be accelerated in comparison to age matched individuals. In recent decades, a number of studies have investigated telomere biology in relation to premature aging disorders and the key findings from these are highlighted in Table 3. However, while these studies have provided some valuable insights 
into the role of telomere biology in the pathogenesis of age-related disease, many aspects of premature aging disorders are not observed as part of normal aging and therefore it is difficult to apply these findings to aging in the general population [40].

Table 3. Telomere biology in premature aging disorders: Clinical observations and aberrant telomere observations associated with premature aging disorders.

\begin{tabular}{|c|c|c|c|c|}
\hline $\begin{array}{c}\text { Premature } \\
\text { Aging Disorder }\end{array}$ & $\begin{array}{l}\text { Characteristic } \\
\text { Symptoms }\end{array}$ & Mutations Observed & $\begin{array}{c}\text { Effects on Telomere } \\
\text { Structure }\end{array}$ & References \\
\hline $\begin{array}{l}\text { Hutchinson-Gilford } \\
\text { Progeria } \\
\text { Syndrome }\end{array}$ & $\begin{array}{l}\text { Hair greying and loss, } \\
\text { decreased joint mobility, } \\
\text { loss of subcutaneous fat } \\
\text { and atherosclerosis }\end{array}$ & $\begin{array}{l}\text { Point mutation in the } L M N A \text { gene } \\
\text { encoding prelamin A; a protein } \\
\text { involved in nuclear lamina. Mutant } \\
L M N A \text { induces DNA damage } \\
\text { response at the telomere leading to } \\
\text { cell senescence }\end{array}$ & Shortened telomere length & [91-93] \\
\hline $\begin{array}{l}\text { Werner } \\
\text { Syndrome }\end{array}$ & $\begin{array}{l}\text { Hair greying and loss, } \\
\text { skin atrophy, diabetes, } \\
\text { osteoporosis, cataracts, } \\
\text { arteriosclerosis } \\
\text { and neoplasms }\end{array}$ & $\begin{array}{l}\text { Mutation in WRN gene located on } \\
\text { the P arm of chromosome } 8 \text {, which } \\
\text { encodes the RecQ DNA helicase } \\
\text { involved in DNA replication, } \\
\text { recombination and repair. } \\
\text { Recruitment of WRN by TERF2 is } \\
\text { essential for resolution of the } \\
\text { telomeric D-loop and synthesis of } \\
\text { the telomeric } 3^{\prime} \text { overhang }\end{array}$ & $\begin{array}{l}\text { Average telomere length is } \\
\text { not reduced. However, loss } \\
\text { of telomeres on individual } \\
\text { sister chromatids is observed } \\
\text { leading to chromosome } \\
\text { breakage-fusion events, } \\
\text { genome instability and cell } \\
\text { senescence. The rate of } \\
\text { overall telomere attrition is } \\
\text { also increased. }\end{array}$ & [94-98] \\
\hline Bloom Syndrome & $\begin{array}{l}\text { Growth retardation, } \\
\text { immunodeficiency, } \\
\text { genomic instability } \\
\text { cancer and } \\
\text { premature menopause }\end{array}$ & $\begin{array}{l}\text { Mutation of BLM; another RecQ } \\
\text { helicase associated with TERF2 and } \\
\text { involved in DNA replication, } \\
\text { recombination and repair }\end{array}$ & $\begin{array}{l}\text { Telomere length is not } \\
\text { reduced. However, the rate } \\
\text { of telomere shortening } \\
\text { is accelerated }\end{array}$ & {$[99-102]$} \\
\hline $\begin{array}{l}\text { Nijmegen } \\
\text { Breakage } \\
\text { Syndrome }\end{array}$ & $\begin{array}{l}\text { Chromosomal instability } \\
\text { and cancers }\end{array}$ & $\begin{array}{l}\text { Mutation of NSB1, which is } \\
\text { involved in DNA repair in } \\
\text { association with TERF2 }\end{array}$ & Shortened telomere length & {$[103,104]$} \\
\hline $\begin{array}{l}\text { Cockayne } \\
\text { Syndrome }\end{array}$ & $\begin{array}{l}\text { Neurological } \\
\text { degeneration, hearing } \\
\text { loss, retinal degeneration } \\
\text { and loss of } \\
\text { subcutaneous fat }\end{array}$ & $\begin{array}{c}\text { Mutation in one of five genes } \\
\text { including } C S A, C S B, X P B, X P D \text { and } \\
X P G \text {. Mutation in } C S B \text { is implicated } \\
\text { in the majority of cases. CSB } \\
\text { interacts with TERF2 as well as } \\
\text { TERF1 to regulate telomere } \\
\text { length maintenance }\end{array}$ & Shortened telomere length & [105-107] \\
\hline $\begin{array}{l}\text { Dyskeratosis } \\
\text { Congenita }\end{array}$ & $\begin{array}{c}\text { Abnormal skin } \\
\text { pigmentation, nail } \\
\text { dystrophy, bone marrow } \\
\text { failure and cancer }\end{array}$ & $\begin{array}{l}\text { One of several mutations involving } \\
\text { telomerase (an enzyme involved in } \\
\text { telomere length maintenance) or } \\
\text { proteins that regulate telomerase. In } \\
\text { the X-linked recessive form, DKC1 } \\
\text { is mutated, which associates with } \\
\text { TERC (the RNA component of } \\
\text { telomerase). In the autosomal } \\
\text { dominant form, TERC is commonly } \\
\text { involved; however TIFN2 is } \\
\text { mutated in some cases. In } \\
\text { autosomal recessive forms, } \\
\text { mutations in TERT (the reverse } \\
\text { transcriptase component of } \\
\text { telomerase), NOP10 and NHP2 are } \\
\text { the cause. NHP2 interacts with } \\
\text { NOP10, which in turn associates } \\
\text { with DKC1 in order to interact } \\
\text { with TERC. }\end{array}$ & $\begin{array}{l}\text { Shortened telomere length. } \\
\text { Furthermore, shorter } \\
\text { telomeres are associated } \\
\text { with more severe } \\
\text { clinical phenotypes }\end{array}$ & [108-112] \\
\hline $\begin{array}{c}\text { Ataxia } \\
\text { telangiectasia }\end{array}$ & $\begin{array}{l}\text { Neurological } \\
\text { deterioration, } \\
\text { chromosomal instability } \\
\text { and predisposition to } \\
\text { cancer }\end{array}$ & $\begin{array}{c}\text { Mutations in ATM, which is located } \\
\text { on the q arm of chromosome } 11 \text { and } \\
\text { is involved in cell cycle progression } \\
\text { and DNA repair pathways }\end{array}$ & $\begin{array}{l}\text { Accelerated telomere } \\
\text { shortening and chromosome } \\
\text { fusion events }\end{array}$ & {$[113,114]$} \\
\hline
\end{tabular}


Table 3. Cont.

\begin{tabular}{|c|c|c|c|c|}
\hline $\begin{array}{c}\text { Premature } \\
\text { Aging Disorder }\end{array}$ & $\begin{array}{c}\text { Characteristic } \\
\text { Symptoms }\end{array}$ & Mutations Observed & $\begin{array}{c}\text { Effects on Telomere } \\
\text { Structure }\end{array}$ & References \\
\hline $\begin{array}{l}\text { Down's } \\
\text { Syndrome }\end{array}$ & $\begin{array}{l}\text { Accelerated aging } \\
\text { characteristics such as } \\
\text { premature skin } \\
\text { wrinkling, greying hair, } \\
\text { hypogonadism, } \\
\text { hypothyroidism, early } \\
\text { menopause and } \\
\text { declining immune } \\
\text { function. In addition } \\
\text { overexpression of } \\
\text { amyloid precursor } \\
\text { protein (APP) on } \\
\text { chromosome 21 leads to } \\
\text { Alzheimer's Disease }\end{array}$ & Trisomy chromosome 21 & Shortened telomere length & [115-117] \\
\hline
\end{tabular}

\subsection{Telomere Length in Age-Related Cardiometabolic and Neurological Disorders}

Several studies have shown that shortened telomeres are associated with cardiovascular disease [118-120], including atherosclerosis [121-123], hypertension [124], vascular dementia [125] and coronary heart disease [126]. Moreover, in many cases telomere length has been identified as an indicator of the severity of such conditions [60,127] and has been associated with risk of stroke, heart attack and mortality $[127,128]$. However, methodological issues, particularly in relation to adjustment for important confounders (e.g., age, gender and ethnicity) mean than drawing robust conclusions from the data is difficult. Furthermore, others have noted that while telomere length itself may not be a risk factor for mortality associated with cardiovascular disease, the rate of telomere attrition is [129].

Type II diabetes is another disease that is recognised as part of the aging phenotype and is one of the most common chronic diseases in the world. Again, this disease shows conflicting results across different studies that have assessed its relationship with telomere length. Initial studies showed that short telomeres are associated with type II diabetes [130,131]; however in prospective studies this association was not always replicated. While some analyses demonstrate shortened telomere length as a risk for type II diabetes, others report no such link [132,133]. A recent meta-analysis argued that this conflicting information may be due to small sample sizes in previous studies and therefore the authors pooled data from a large number of studies, concluding that shortened telomeres are associated with type II diabetes [134]. The authors point out however, that the strength of association in sub-group analysis was influenced by age and that other studies identify additional influencers of telomere length such as gender and ethnicity. Information on these factors was insufficient for such analysis in their own study and therefore further research is warranted [134].

Similar conclusions can be drawn from studies that have investigated telomere length in Alzheimer's disease patients and in those suffering with dementia. Several studies show that affected individuals possess shortened leukocyte telomere lengths in comparison to age matched controls [135-139], however the data that associates severity of disease with telomere length is less clear-cut. While some show that telomere lengths of dementia and Alzheimer's disease patients are correlated with disease status [136,138,139] others have not [140-142].

In addition, studies that have investigated telomere length in Parkinson's disease patients show similar results. Although telomere length has been shown to be reduced compared to controls in one study [143], this was not observed in another [144]. Furthermore, a third study found that individuals with shortest telomere lengths were three fold less likely to develop Parkinson's disease [145]. That being said, it has been noted that the range of telomere lengths is altered in Parkinson's disease patients, with lengths of less than $5 \mathrm{~kb}$ only observed in patients and not controls. Furthermore, in older individuals (above 60 years old), the percentage of short telomeres increased over time in comparison to controls [144]. 


\subsection{Telomeres, Tumorigenesis and Cancer}

Cancer, which is defined as the uncontrolled growth of abnormal cells, is the leading cause of death worldwide [146] with advancing age being the most significant risk factor [147]. Cancer cells are typically characterised by chaotic genome instability and immortality as a result of an acquired means to circumvent normal replicative barriers. Therefore, the finite replicative capacity of the cell is vital in the prevention of cancer and in this sense, telomere function may also be extended to the protection against cancer. Once telomere degradation has reached a critical level, the cell is committed to pathways that ultimately result in senescence or apoptosis and thus telomeres protect the integrity of the genome. However in the event that this mechanism should fail, tumorigenesis ensues [148].

Tumorigenesis is considered to be a three-step process, in which cancer cells evolve the ability to overcome committal to senescence. First, are the loss of telomeric repeat sequences and/or the loss of the telosome structure, which may occur independently of or as a result of the former [149]. Second is the inappropriate action of non-homologous end joining (NHEJ) or homology direction repair (HDR) machinery, which may recognise uncapped telomeres as DNA breaks. Such action results in the fusion of chromosomes at their ends, generating dicentric chromosomes which are subsequently pulled apart during cell division, creating further breakages. This breakage-bridge-fusion cycle continues during successive cell divisions resulting in duplication of whole chromosomes, aneuploidy, gene amplifications, translocations, inversions and deletions [150]. Such complex chromosome rearrangements add further oncogenic potential via deregulation of oncogenes or altered gene dosage [151-153]. This second stage, known as the crisis stage, drives malignant transformation via the ability to evade apoptosis mechanisms [154]. Furthermore, as more successive divisions occur, telomeres shorten further, encouraging more chromosomes to enter breakage-fusion-bridge cycles and an accumulation of genomic instability [150]. Finally, these malignant cells must acquire immortality in order to continue cell division unchecked. In $90 \%$ of cancers, this is achieved via the expression of telomerase, which is inactive in normal somatic cells and acts to maintain telomere length in a shortened state [155]. Less commonly, this maintenance is achieved via ALT [156].

With the above in mind, it is widely believed that shortened telomeres are both a protector (when recognised via the appropriate mechanisms) and an initiator (when not recognised) of tumorigenesis. In recent decades, it has also been increasingly recognised that a single short telomere may be sufficient to initiate tumorigenesis and that telomerase action may be tightly controlled, such that it may selectively act upon only the shortest telomeres. This in turn leads to the maintenance of a shortened state, synchronous with other chromosomes within the population of cells rather than elongation beyond the length of other chromosomes. Therefore, in many (but not all) tumours, overall telomere length may be unchanged or remain shortened in comparison to normal neighbouring cells [157-159].

Given the association between shortened, dysfunctional telomeres and tumorigenesis it is unsurprising that many researchers have investigated the relationship between telomere length and a variety of specific cancers. In similarity to its relationship with chronological age, the relationship between telomere length and cancer is equally difficult to draw robust conclusions from. The majority of studies report shortened telomere length and some have additionally found that the degree of malignancy and prognosis were also associated with telomere length $[160,161]$. However this appears to be specific to certain types of cancer. In meta-analyses, telomere length was shown to be shortened in bladder, oesophageal, gastric, head and neck, ovarian and renal cancers [160]. Short telomeres and telomerase mutations are also associated with hepatocarcinoma [162,163]. However, no association with telomere length was observed in endometrial, prostate and skin cancer. Furthermore, an assessment of the association between telomere length in non-Hodgkin's lymphoma, breast, lung and colorectal cancer proved inconclusive [160]. Moreover, a recent systematic analysis of telomere length in 31 cancers showed that while overall, telomere length was shortened in tumour compared to normal tissues, many tumour types showed telomere elongation in a proportion of samples assessed. In three tumour types (testicular germ cell carcinoma, lower grade glioma and sarcoma), over $50 \%$ of samples showed telomere elongation [164]. Similarly, contradictory results are 
available from a variety of studies that have associated telomere length with the risk of developing cancer. While some studies report that longer telomeres are associated with an increased risk of developing cancer [165-167], others argue that shortened telomeres increase cancer risk [160,168,169]. These discrepancies may at least in part, be down to differences in study design. Prospective studies assess telomere length prior to diagnosis and therefore prior to the crisis stage of tumorigenesis when telomeres are longer and inhibit the protective effects of senescence whereas retrospective studies assess telomere length after cancer diagnosis and therefore after the crisis stage of tumorigenesis when telomeres are shorter and genomic instability ensues [165,170].

\section{Conclusions and Perspectives}

Since their discovery in 1939, our knowledge of telomere biology has continued to advance in leaps and bounds. Available data suggest that telomere attrition is associated with cellular senescence, the process of aging and the pathogenesis of many diseases. However, whilst these findings are both interesting and invaluable areas of uncertainty remain. Firstly, it must be recognised that association does not imply causality and the observational nature of telomere studies precludes any causal inferences. Secondly, whether shortening of telomeres observed is cause, effect or both is not well established. In addition, high inter-individual variability in telomere length suggests that many other factors besides chronological age may act as influencers (Table 2). Furthermore, many other factors in addition to telomere shortening may contribute to the process of aging at the cellular, organ and organismal level. For example genetic, epigenetic, environmental and lifestyle factors $[171,172]$ have been implicated in addition to mechanisms that regulate protein homeostasis, nutrient sensing [173] and mitochondrial function $[173,174]$.

It is important to recognise that telomere length is a difficult parameter to measure and therefore technical factors in any study design may also impose significant problems in the interpretation of study results. For example, sample storage conditions and the methodology used to extract DNA and measure telomere length [175-177] may have an effect on the results obtained. In the context of studies that have assessed telomere length in relation to the onset of disease, the origin of the sample (e.g., the cell type and whether the sample is specific to the affected tissue or a surrogate sample) [160], the type of controls used (paired samples with normal controls from the same individual or unpaired samples with controls from healthy donors) the timing of the sample (prior to or subsequent to the onset of disease) and the administration of any treatment [165] may have additional effects. In the future therefore, research efforts should employ carefully designed, robust and reproducible methodologies in order to further our understanding of how the complex mechanisms that orchestrate the relationship between telomere biology and the process of aging and disease are interwoven.

Author Contributions: K.J.T.: writing-original draft preparation, writing-review and editing. V.V.: writing - original draft preparation, writing-review and editing. D.K.G.: supervision, writing-review and editing.

Funding: The preparation of this review article received no external funding.

Conflicts of Interest: The authors declare no conflict of interest. The funders had no role in the preparation or writing of the manuscript or in the decision to publish this review.

\section{References}

1. Blackburn, E.; Szostak, J. The molecular structure of centromeres and telomeres. Annu. Rev. Biochem. 1984, 53, 163-194. [CrossRef] [PubMed]

2. Meyne, J.; Ratliff, R.L.; MoYzIs, R.K. Conservation of the human telomere sequence (TTAGGG) $\mathrm{n}$ among vertebrates. Proc. Natl. Acad. Sci. USA 1989, 86, 7049-7053. [CrossRef] [PubMed]

3. De Lange, T. Shelterin: The protein complex that shapes and safeguards human telomeres. Genes Dev. 2005, 19, 2100-2110. [CrossRef] [PubMed]

4. De Lange, T. T-loops and the origin of telomeres. Nat. Rev. Mol. Cell Biol. 2004, 5, 323-329. [CrossRef] [PubMed] 
5. Webb, C.J.; Wu, Y.; Zakian, V.A. DNA repair at telomeres: Keeping the ends intact. Cold Spring Harb. Perspect. Biol. 2013, 5, a012666. [CrossRef] [PubMed]

6. Bailey, S.M.; Meyne, J.; Chen, D.J.; Kurimasa, A.; Li, G.C.; Lehnert, B.E.; Goodwin, E.H. DNA double-strand break repair proteins are required to cap the ends of mammalian chromosomes. Proc. Natl. Acad. Sci. USA 1999, 96, 14899-14904. [CrossRef] [PubMed]

7. Bailey, S.M.; Murnane, J.P. Telomeres, chromosome instability and cancer. Nucleic Acids Res. 2006, 34, 2408-2417. [CrossRef]

8. Dechat, T.; Gajewski, A.; Korbei, B.; Gerlich, D.; Daigle, N.; Haraguchi, T.; Furukawa, K.; Ellenberg, J.; Foisner, R. LAP2 $\alpha$ and BAF transiently localize to telomeres and specific regions on chromatin during nuclear assembly. J. Cell Sci. 2004, 117, 6117-6128. [CrossRef]

9. Novo, C.L.; Londono-Vallejo, J.A. Telomeres and the nucleus. Semin. Cancer Biol. 2013, 23, 116-124. [CrossRef]

10. Blasco, M.A. The epigenetic regulation of mammalian telomeres. Nat. Rev. Genet. 2007, 8, 299. [CrossRef]

11. Xin, H.; Liu, D.; Songyang, Z. The telosome/shelterin complex and its functions. Genome Biol. $2008,9,232$. [CrossRef] [PubMed]

12. Lazzerini-Denchi, E.; Sfeir, A. Stop pulling my strings-What telomeres taught us about the DNA damage response. Nat. Rev. Mol. Cell Biol. 2016, 17, 364. [CrossRef]

13. Lei, M.; Podell, E.R.; Cech, T.R. Structure of human POT1 bound to telomeric single-stranded DNA provides a model for chromosome end-protection. Nat. Struct. Mol. Biol. 2004, 11, 1223-1229. [CrossRef] [PubMed]

14. Ohki, R.; Tsurimoto, T.; Ishikawa, F. In vitro reconstitution of the end replication problem. Mol. Cell. Biol. 2001, 21, 5753-5766. [CrossRef] [PubMed]

15. Okazaki, R.; Okazaki, T.; Sakabe, K.; Sugimoto, K.; Sugino, A. Mechanism of DNA chain growth. I. Possible discontinuity and unusual secondary structure of newly synthesized chains. Proc. Natl. Acad. Sci. USA 1968, 59, 598-605. [CrossRef] [PubMed]

16. Watson, J.D. Origin of concatemeric T7DNA. Nature 1972, 239, 197-201. [CrossRef]

17. Ohki, R.; Ishikawa, F. Telomere-bound TRF1 and TRF2 stall the replication fork at telomeric repeats. Nucleic Acids Res. 2004, 32, 1627-1637. [CrossRef]

18. Greider, C.W.; Blackburn, E.H. A telomeric sequence in the RNA of Tetrahymena telomerase required for telomere repeat synthesis. Nature 1989, 337, 331-337. [CrossRef]

19. Azzalin, C.M.; Reichenbach, P.; Khoriauli, L.; Giulotto, E.; Lingner, J. Telomeric repeat-containing RNA and RNA surveillance factors at mammalian chromosome ends. Science 2007, 318, 798-801. [CrossRef]

20. Redon, S.; Reichenbach, P.; Lingner, J. The non-coding RNA TERRA is a natural ligand and direct inhibitor of human telomerase. Nucleic Acids Res. 2010, 38, 5797-5806. [CrossRef]

21. Henson, J.D.; Neumann, A.A.; Yeager, T.R.; Reddel, R.R. Alternative lengthening of telomeres in mammalian cells. Oncogene 2002, 21, 598. [CrossRef] [PubMed]

22. Hiyama, E.; Hiyama, K. Telomere and telomerase in stem cells. Br. J. Cancer 2007, 96, 1020. [CrossRef]

23. Hayflick, L.; Moorhead, P.S. The serial cultivation of human diploid cell strains. Exp. Cell Res. 1961, 25, 585-621. [CrossRef]

24. Harley, C.B.; Futcher, A.B.; Greider, C.W. Telomeres shorten during ageing of human fibroblasts. Nature 1990, 345, 458-460. [CrossRef] [PubMed]

25. Allsopp, R.C.; Vaziri, H.; Patterson, C.; Goldstein, S.; Younglai, E.V.; Futcher, A.B.; Greider, C.W.; Harley, C.B. Telomere length predicts replicative capacity of human fibroblasts. Proc. Natl. Acad. Sci. USA 1992, 89, 10114-10118. [CrossRef] [PubMed]

26. Shay, J.W.; Wright, W.E. Hayflick, his limit, and cellular ageing. Nat. Rev. Mol. Cell Biol. 2000, 1, 72. [CrossRef] [PubMed]

27. Hastie, N.D.; Dempster, M.; Dunlop, M.G.; Thompson, A.M.; Green, D.K.; Allshire, R.C. Telomere reduction in human colorectal carcinoma and with ageing. Nature 1990, 346, 866-868. [CrossRef]

28. Lindsey, J.; McGill, N.I.; Lindsey, L.A.; Green, D.K.; Cooke, H.J. In vivo loss of telomeric repeats with age in humans. Mutat. Res. 1991, 256, 45-48. [CrossRef]

29. Frenck, R.W., Jr.; Blackburn, E.H.; Shannon, K.M. The rate of telomere sequence loss in human leukocytes varies with age. Proc. Natl. Acad. Sci. USA 1998, 95, 5607-5610. [CrossRef]

30. Zeichner, S.L.; Palumbo, P.; Feng, Y.; Xiao, X.; Gee, D.; Sleasman, J.; Goodenow, M.; Biggar, R.; Dimitrov, D. Rapid telomere shortening in children. Blood 1999, 93, 2824-2830. 
31. Rufer, N.; Brümmendorf, T.H.; Kolvraa, S.; Bischoff, C.; Christensen, K.; Wadsworth, L.; Schulzer, M.; Lansdorp, P.M. Telomere fluorescence measurements in granulocytes and T lymphocyte subsets point to a high turnover of hematopoietic stem cells and memory T cells in early childhood. J. Exp. Med. 1999, 190, 157-168. [CrossRef] [PubMed]

32. Takubo, K.; Nakamura, K.-I.; Izumiyama, N.; Furugori, E.; Sawabe, M.; Arai, T.; Esaki, Y.; Mafune, K.-I.; Kammori, M.; Fujiwara, M. Telomere shortening with aging in human liver. J. Gerontol. A Biol. Sci. Med. Sci. 2000, 55, B533-B536. [CrossRef] [PubMed]

33. Takubo, K.; Nakamura, K.-I.; Izumiyama, N.; Sawabe, M.; Arai, T.; Esaki, Y.; Tanaka, Y.; Mafune, K.-I.; Fujiwara, M.; Kammori, M. Telomere shortening with aging in human esophageal mucosa. Age 1999, 22, 95-99. [CrossRef] [PubMed]

34. Lansdorp, P.M. Telomeres, stem cells, and hematology. Blood 2008, 111, 1759-1766. [CrossRef] [PubMed]

35. Longhese, M.P. DNA damage response at functional and dysfunctional telomeres. Genes Dev. 2008, 22, 125-140. [CrossRef]

36. Shay, J.W. Telomerase therapeutics: Telomeres recognized as a DNA damage signal. Clin. Cancer Res. 2003, 9 , 3521-3525.

37. Muñoz-Espín, D.; Serrano, M. Cellular senescence: From physiology to pathology. Nat. Rev. Mol. Cell Biol. 2014, 15, 482-496. [CrossRef]

38. Vicencio, J.M.; Galluzzi, L.; Tajeddine, N.; Ortiz, C.; Criollo, A.; Tasdemir, E.; Morselli, E.; Ben Younes, A.; Maiuri, M.C.; Lavandero, S. Senescence, apoptosis or autophagy? Gerontology 2008, 54, 92-99. [CrossRef]

39. Armanios, M. Telomeres and age-related disease: How telomere biology informs clinical paradigms. J. Clin. Investig. 2013, 123, 996-1002. [CrossRef]

40. Sanders, J.L.; Newman, A.B. Telomere Length in Epidemiology: A Biomarker of Aging, Age-Related Disease, Both, or Neither? Epidemiol. Rev. 2013, 35, 112-131. [CrossRef]

41. Von Zglinicki, T.; Martin-Ruiz, C.M. Telomeres as biomarkers for ageing and age-related diseases. Curr. Mol. Med. 2005, 5, 197-203. [CrossRef] [PubMed]

42. Turner, S.; Wong, H.P.; Rai, J.; Hartshorne, G.M. Telomere lengths in human oocytes, cleavage stage embryos and blastocysts. Mol. Hum. Reprod. 2010. [CrossRef] [PubMed]

43. Wright, D.L.; Jones, E.L.; Mayer, J.F.; Oehninger, S.; Gibbons, W.E.; Lanzendorf, S.E. Characterization of telomerase activity in the human oocyte and preimplantation embryo. Mol. Hum. Reprod. 2001, 7, 947-955. [CrossRef] [PubMed]

44. Cheng, G.; Kong, F.; Luan, Y.; Sun, C.; Wang, J.; Zhang, L.; Jiang, B.; Qi, T.; Zhao, J.; Zheng, C. Differential shortening rate of telomere length in the development of human fetus. Biochem. Biophys. Res. Commun. 2013, 442, 112-115. [CrossRef] [PubMed]

45. Youngren, K.; Jeanclos, E.; Aviv, H.; Kimura, M.; Stock, J.; Hanna, M.; Skurnick, J.; Bardeguez, A.; Aviv, A. Synchrony in telomere length of the human fetus. Hum. Genet. 1998, 102, 640-643. [CrossRef] [PubMed]

46. Holmes, D.K.; Bellantuono, I.; Walkinshaw, S.A.; Alfirevic, Z.; Johnston, T.A.; Subhedar, N.V.; Chittick, R.; Swindell, R.; Wynn, R.F. Telomere length dynamics differ in foetal and early post-natal human leukocytes in a longitudinal study. Biogerontology 2009, 10, 279-284. [CrossRef] [PubMed]

47. Wright, W.E.; Piatyszek, M.A.; Rainey, W.E.; Byrd, W.; Shay, J.W. Telomerase activity in human germline and embryonic tissues and cells. Dev. Genet. 1996, 18, 173-179. [CrossRef]

48. Ulaner, G.A.; Giudice, L.C. Developmental regulation of telomerase activity in human fetal tissues during gestation. Mol. Hum. Reprod. 1997, 3, 769-773. [CrossRef]

49. Vasu, V.; Turner, K.J.; George, S.; Greenall, J.; Slijepcevic, P.; Griffin, D.K. Preterm infants have significantly longer telomeres than their term born counterparts. PLOS ONE 2017, 12, e0180082. [CrossRef]

50. Friedrich, U.; Schwab, M.; Griese, E.U.; Fritz, P.; Klotz, U. Telomeres in neonates: New insights in fetal hematopoiesis. Pediatr. Res. 2001, 49, 252-256. [CrossRef]

51. Menon, R.; Yu, J.; Basanta-Henry, P.; Brou, L.; Berga, S.L.; Fortunato, S.J.; Taylor, R.N. Short fetal leukocyte telomere length and preterm prelabor rupture of the membranes. PLoS ONE 2012, 7, e31136. [CrossRef] [PubMed]

52. Okuda, K.; Bardeguez, A.; Gardner, J.P.; Rodriguez, P.; Ganesh, V.; Kimura, M.; Skurnick, J.; Awad, G.; Aviv, A. Telomere length in the newborn. Pediatr. Res. 2002, 52, 377-381. [CrossRef] [PubMed]

53. Akkad, A.; Hastings, R.; Konje, J.C.; Bell, S.C.; Thurston, H.; Williams, B. Telomere length in small-for-gestational-age babies. BJOG 2006, 113, 318-323. [CrossRef] [PubMed] 
54. Factor-Litvak, P.; Susser, E.; Kezios, K.; McKeague, I.; Kark, J.D.; Hoffman, M.; Kimura, M.; Wapner, R.; Aviv, A. Leukocyte telomere length in newborns: Implications for the role of telomeres in human disease. Pediatrics 2016. [CrossRef] [PubMed]

55. Njajou, O.T.; Cawthon, R.M.; Damcott, C.M.; Wu, S.H.; Ott, S.; Garant, M.J.; Blackburn, E.H.; Mitchell, B.D.; Shuldiner, A.R.; Hsueh, W.C. Telomere length is paternally inherited and is associated with parental lifespan. Proc. Natl. Acad. Sci. USA 2007, 104, 12135-12139. [CrossRef] [PubMed]

56. Nordfjäll, K.; Larefalk, Å.; Lindgren, P.; Holmberg, D.; Roos, G. Telomere length and heredity: Indications of paternal inheritance. Proc. Natl. Acad. Sci. USA 2005, 102, 16374-16378. [CrossRef] [PubMed]

57. Friedrich, U.; Griese, E.-U.; Schwab, M.; Fritz, P.; Thon, K.-P.; Klotz, U. Telomere length in different tissues of elderly patients. Mech. Ageing Dev. 2000, 119, 89-99. [CrossRef]

58. Daniali, L.; Benetos, A.; Susser, E.; Kark, J.D.; Labat, C.; Kimura, M.; Desai, K.K.; Granick, M.; Aviv, A. Telomeres shorten at equivalent rates in somatic tissues of adults. Nat. Commun. 2013, 4, 1597. [CrossRef]

59. Nordfjäll, K.; Eliasson, M.; Stegmayr, B.; Melander, O.; Nilsson, P.; Roos, G. Telomere length is associated with obesity parameters but with a gender difference. Obesity 2008, 16, 2682-2689. [CrossRef]

60. Willeit, P.; Willeit, J.; Brandstätter, A.; Ehrlenbach, S.; Mayr, A.; Gasperi, A.; Weger, S.; Oberhollenzer, F.; Reindl, M.; Kronenberg, F. Cellular aging reflected by leukocyte telomere length predicts advanced atherosclerosis and cardiovascular disease risk. Arterioscler. Thromb. Vasc. Biol. 2010, 30, 1649-1656. [CrossRef]

61. Henckel, E.; Svenson, U.; Nordlund, B.; Berggren Broström, E.; Hedlin, G.; Degerman, S.; Bohlin, K. Telomere length was similar in school-age children with bronchopulmonary dysplasia and allergic asthma. Acta Paediatr. 2018, 107, 1395-1401. [CrossRef] [PubMed]

62. Aviv, A.; Chen, W.; Gardner, J.P.; Kimura, M.; Brimacombe, M.; Cao, X.; Srinivasan, S.R.; Berenson, G.S. Leukocyte telomere dynamics: Longitudinal findings among young adults in the Bogalusa Heart Study. Am. J. Epidemiol. 2009, 169, 323-329. [CrossRef] [PubMed]

63. Benetos, A.; Kark, J.D.; Susser, E.; Kimura, M.; Sinnreich, R.; Chen, W.; Steenstrup, T.; Christensen, K.; Herbig, U.; von Bornemann Hjelmborg, J. Tracking and fixed ranking of leukocyte telomere length across the adult life course. Aging Cell 2013, 12, 615-621. [CrossRef] [PubMed]

64. Andrew, T.; Aviv, A.; Falchi, M.; Surdulescu, G.L.; Gardner, J.P.; Lu, X.; Kimura, M.; Kato, B.S.; Valdes, A.M.; Spector, T.D. Mapping genetic loci that determine leukocyte telomere length in a large sample of unselected female sibling pairs. Am. J. Hum. Genet. 2006, 78, 480-486. [CrossRef]

65. Codd, V.; Nelson, C.P.; Albrecht, E.; Mangino, M.; Deelen, J.; Buxton, J.L.; Hottenga, J.J.; Fischer, K.; Esko, T.; Surakka, I. Identification of seven loci affecting mean telomere length and their association with disease. Nat. Genet. 2013, 45, 422-427. [CrossRef] [PubMed]

66. Mangino, M.; Hwang, S.-J.; Spector, T.D.; Hunt, S.C.; Kimura, M.; Fitzpatrick, A.L.; Christiansen, L.; Petersen, I.; Elbers, C.C.; Harris, T. Genome-wide meta-analysis points to CTC1 and ZNF676 as genes regulating telomere homeostasis in humans. Hum. Mol. Genet. 2012, 21, 5385-5394. [CrossRef] [PubMed]

67. Hjelmborg, J.B.; Dalgård, C.; Möller, S.; Steenstrup, T.; Kimura, M.; Christensen, K.; Kyvik, K.O.; Aviv, A. The heritability of leucocyte telomere length dynamics. J. Med. Genet. 2015, 52, 297-302. [CrossRef]

68. Kyo, S.; Takakura, M.; Kanaya, T.; Zhuo, W.; Fujimoto, K.; Nishio, Y.; Orimo, A.; Inoue, M. Estrogen activates telomerase. Cancer Res. 1999, 59, 5917-5921.

69. Simoncini, T.; Hafezi-Moghadam, A.; Brazil, D.P.; Ley, K.; Chin, W.W.; Liao, J.K. Interaction of oestrogen receptor with the regulatory subunit of phosphatidylinositol-3-OH kinase. Nature 2000, 407, 538-541. [CrossRef]

70. Kang, S.S.; Kwon, T.; Do, S.I. Akt protein kinase enhances human telomerase activity through phosphorylation of telomerase reverse transcriptase subunit. J. Biol. Chem. 1999, 274, 13085-13090. [CrossRef]

71. Diez Roux, A.V.; Ranjit, N.; Jenny, N.S.; Shea, S.; Cushman, M.; Fitzpatrick, A.; Seeman, T. Race/ethnicity and telomere length in the Multi-Ethnic Study of Atherosclerosis. Aging Cell 2009, 8, 251-257. [CrossRef]

72. Epel, E.S. Psychological and metabolic stress: A recipe for accelerated cellular aging. Hormones 2009, 8, 7-22. [CrossRef] [PubMed]

73. Simon, N.M.; Smoller, J.W.; McNamara, K.L.; Maser, R.S.; Zalta, A.K.; Pollack, M.H.; Nierenberg, A.A.; Fava, M.; Wong, K.-K. Telomere shortening and mood disorders: Preliminary support for a chronic stress model of accelerated aging. Biol. Psychiatry 2006, 60, 432-435. [CrossRef] 
74. Wolkowitz, O.M.; Mellon, S.H.; Epel, E.S.; Lin, J.; Dhabhar, F.S.; Su, Y.; Reus, V.I.; Rosser, R.; Burke, H.M.; Kupferman, E. Leukocyte telomere length in major depression: Correlations with chronicity, inflammation and oxidative stress-preliminary findings. PLoS ONE 2011, 6, e17837. [CrossRef] [PubMed]

75. Cherkas, L.F.; Hunkin, J.L.; Kato, B.S.; Richards, J.B.; Gardner, J.P.; Surdulescu, G.L.; Kimura, M.; Lu, X.; Spector, T.D.; Aviv, A. The association between physical activity in leisure time and leukocyte telomere length. Arch. Intern. Med. 2008, 168, 154-158. [CrossRef] [PubMed]

76. Puterman, E.; Lin, J.; Blackburn, E.; O’Donovan, A.; Adler, N.; Epel, E. The power of exercise: Buffering the effect of chronic stress on telomere length. PLoS ONE 2010, 5, e10837. [CrossRef] [PubMed]

77. Ludlow, A.T.; Zimmerman, J.B.; Witkowski, S.; Hearn, J.W.; Hatfield, B.D.; Roth, S.M. Relationship between physical activity level, telomere length, and telomerase activity. Med. Sci. Sports Exerc. 2008, 40, 1764. [CrossRef] [PubMed]

78. Valdes, A.; Andrew, T.; Gardner, J.A.; Kimura, M.; Oelsner, E.; Cherkas, L.; Aviv, A.; Spector, T. Obesity, cigarette smoking, and telomere length in women. Lancet 2005, 366, 662-664. [CrossRef]

79. Das, U.N. Metabolic syndrome X: An inflammatory condition? Curr. Hypertens. Rep. 2004, 6, 66-73. [CrossRef]

80. Furukawa, S.; Fujita, T.; Shimabukuro, M.; Iwaki, M.; Yamada, Y.; Nakajima, Y.; Nakayama, O.; Makishima, M.; Matsuda, M.; Shimomura, I. Increased oxidative stress in obesity and its impact on metabolic syndrome. J. Clin. Investig. 2004, 114, 1752-1761. [CrossRef]

81. Carulli, L.; Anzivino, C.; Baldelli, E.; Zenobii, M.; Rocchi, M.B.L.; Bertolotti, M. Telomere length elongation after weight loss intervention in obese adults. Mol. Genet. Metab. 2016, 118, 138-142. [CrossRef] [PubMed]

82. McGrath, M.; Wong, J.Y.; Michaud, D.; Hunter, D.J.; De Vivo, I. Telomere length, cigarette smoking, and bladder cancer risk in men and women. Cancer Epidemiol. Biomark. Prev. 2007, 16, 815-819. [CrossRef] [PubMed]

83. Pavanello, S.; Hoxha, M.; Dioni, L.; Bertazzi, P.A.; Snenghi, R.; Nalesso, A.; Ferrara, S.D.; Montisci, M.; Baccarelli, A. Shortened telomeres in individuals with abuse in alcohol consumption. Int. J. Cancer 2011, 129, 983-992. [CrossRef] [PubMed]

84. Childs, B.G.; Durik, M.; Baker, D.J.; Van Deursen, J.M. Cellular senescence in aging and age-related disease: From mechanisms to therapy. Nat. Med. 2015, 21, 1424. [CrossRef] [PubMed]

85. Collado, M.; Blasco, M.A.; Serrano, M. Cellular senescence in cancer and aging. Cell 2007, 130, $223-233$. [CrossRef] [PubMed]

86. Wiley, C.D.; Velarde, M.C.; Lecot, P.; Liu, S.; Sarnoski, E.A.; Freund, A.; Shirakawa, K.; Lim, H.W.; Davis, S.S.; Ramanathan, A. Mitochondrial dysfunction induces senescence with a distinct secretory phenotype. Cell Metab. 2016, 23, 303-314. [CrossRef] [PubMed]

87. Passos, J.F.; Saretzki, G.; von Zglinicki, T. DNA damage in telomeres and mitochondria during cellular senescence: Is there a connection? Nucleic Acids Res. 2007, 35, 7505-7513. [CrossRef]

88. Jenny, N.S. Inflammation in aging: Cause, effect, or both? Discov. Med. 2012, 13, 451-460.

89. Finkel, T.; Holbrook, N.J. Oxidants, oxidative stress and the biology of ageing. Nature 2000, 408, 239. [CrossRef]

90. Oikawa, S.; Kawanishi, S. Site-specific DNA damage at GGG sequence by oxidative stress may accelerate telomere shortening. FEBS Lett. 1999, 453, 365-368. [CrossRef]

91. De Sandre-Giovannoli, A.; Bernard, R.; Cau, P.; Navarro, C.; Amiel, J.; Boccaccio, I.; Lyonnet, S.; Stewart, C.L.; Munnich, A.; Le Merrer, M. Lamin a truncation in Hutchinson-Gilford progeria. Science 2003, 300, 2055. [CrossRef] [PubMed]

92. Decker, M.L.; Chavez, E.; Vulto, I.; Lansdorp, P.M. Telomere length in Hutchinson-Gilford progeria syndrome. Mech. Ageing Dev. 2009, 130, 377-383. [CrossRef] [PubMed]

93. Benson, E.K.; Lee, S.W.; Aaronson, S.A. Role of progerin-induced telomere dysfunction in HGPS premature cellular senescence. J. Cell Sci. 2010, 123, 2605-2612. [CrossRef]

94. Goto, M.; Rubenstein, M.; Weber, J.; Woods, K.; Drayna, D. Genetic linkage of Werner's syndrome to five markers on chromosome 8. Nature 1992, 355, 735-738. [CrossRef] [PubMed]

95. Schulz, V.P.; Zakian, V.A.; Ogburn, C.E.; McKay, J.; Jarzebowicz, A.A.; Martin, G.; Edland, S. Accelerated loss of telomeric repeats may not explain accelerated replicative decline of Werner syndrome cells. Hum. Genet. 1996, 97, 750-754. [CrossRef] [PubMed] 
96. Baird, D.M.; Davis, T.; Rowson, J.; Jones, C.J.; Kipling, D. Normal telomere erosion rates at the single cell level in Werner syndrome fibroblast cells. Hum. Mol. Genet. 2004, 13, 1515-1524. [CrossRef] [PubMed]

97. Opresko, P.L.; Otterlei, M.; Graakjær, J.; Bruheim, P.; Dawut, L.; Kølvraa, S.; May, A.; Seidman, M.M.; Bohr, V.A. The Werner syndrome helicase and exonuclease cooperate to resolve telomeric D loops in a manner regulated by TRF1 and TRF2. Mol. Cell 2004, 14, 763-774. [CrossRef]

98. Crabbe, L.; Jauch, A.; Naeger, C.M.; Holtgreve-Grez, H.; Karlseder, J. Telomere dysfunction as a cause of genomic instability in Werner syndrome. Proc. Natl. Acad. Sci. USA 2007, 104, 2205-2210. [CrossRef]

99. Stavropoulos, D.J.; Bradshaw, P.S.; Li, X.; Pasic, I.; Truong, K.; Ikura, M.; Ungrin, M.; Meyn, M.S. The Bloom syndrome helicase BLM interacts with TRF2 in ALT cells and promotes telomeric DNA synthesis. Hum. Mol. Genet. 2002, 11, 3135-3144. [CrossRef]

100. Yankiwski, V.; Marciniak, R.A.; Guarente, L.; Neff, N.F. Nuclear structure in normal and Bloom syndrome cells. Proc. Natl. Acad. Sci. USA 2000, 97, 5214-5219. [CrossRef]

101. German, J. Bloom syndrome: A mendelian prototype of somatic mutational disease. Medicine 1993, 72, 393-406. [CrossRef] [PubMed]

102. Neff, N.F.; Ellis, N.A.; Ye, T.Z.; Noonan, J.; Huang, K.; Sanz, M.; Proytcheva, M. The DNA helicase activity of BLM is necessary for the correction of the genomic instability of Bloom syndrome cells. Mol. Biol. Cell 1999, 10, 665-676. [CrossRef] [PubMed]

103. Shiloh, Y. Ataxia-telangiectasia and the Nijmegen breakage syndrome: Related disorders but genes apart. Annu. Rev. Genet. 1997, 31, 635-662. [CrossRef] [PubMed]

104. Ranganathan, V.; Heine, W.F.; Ciccone, D.N.; Rudolph, K.L.; Wu, X.; Chang, S.; Hai, H.; Ahearn, I.M.; Livingston, D.M.; Resnick, I. Rescue of a telomere length defect of Nijmegen breakage syndrome cells requires NBS and telomerase catalytic subunit. Curr. Biol. 2001, 11, 962-966. [CrossRef]

105. Stevnsner, T.; Muftuoglu, M.; Aamann, M.D.; Bohr, V.A. The role of Cockayne Syndrome group B (CSB) protein in base excision repair and aging. Mech. Ageing Dev. 2008, 129, 441-448. [CrossRef] [PubMed]

106. Laugel, V.; Dalloz, C.; Durand, M.; Sauvanaud, F.; Kristensen, U.; Vincent, M.-C.; Pasquier, L.; Odent, S.; Cormier-Daire, V.; Gener, B. Mutation update for the CSB/ERCC6 and CSA/ERCC8 genes involved in Cockayne syndrome. Hum. Mutat. 2010, 31, 113-126. [CrossRef]

107. Batenburg, N.L.; Mitchell, T.R.; Leach, D.M.; Rainbow, A.J.; Zhu, X.-D. Cockayne Syndrome group B protein interacts with TRF2 and regulates telomere length and stability. Nucleic Acids Res. 2012, 40, 9661-9674. [CrossRef]

108. Heiss, N.; Knight, S.; Vulliamy, T.; Klauck, S.; Wiemann, S.; Mason, P.; Poustka, A.; Dokal, I. X-linked dyskeratosis congenita is caused by mutations in a highly conserved gene with putative nucleolar functions. Nat. Genet. 1998, 19, 32. [CrossRef]

109. Mitchell, J.R.; Wood, E.; Collins, K. A telomerase component is defective in the human disease dyskeratosis congenita. Nature 1999, 402, 551-555. [CrossRef]

110. Vulliamy, T.; Beswick, R.; Kirwan, M.; Marrone, A.; Digweed, M.; Walne, A.; Dokal, I. Mutations in the telomerase component NHP2 cause the premature ageing syndrome dyskeratosis congenita. Proc. Natl. Acad. Sci. USA 2008, 105, 8073-8078. [CrossRef]

111. Savage, S.A.; Giri, N.; Baerlocher, G.M.; Orr, N.; Lansdorp, P.M.; Alter, B.P. TINF2, a Component of the Shelterin Telomere Protection Complex, Is Mutated in Dyskeratosis Congenita. Am. J. Med. Genet. 2008, 82, 501-509. [CrossRef] [PubMed]

112. Walne, A.J.; Vulliamy, T.; Marrone, A.; Beswick, R.; Kirwan, M.; Masunari, Y.; Al-Qurashi, F.-H.; Aljurf, M.; Dokal, I. Genetic heterogeneity in autosomal recessive dyskeratosis congenita with one subtype due to mutations in the telomerase-associated protein NOP10. Hum. Mol. Genet. 2007, 16, 1619-1629. [CrossRef] [PubMed]

113. Savitsky, K.; Bar-Shira, A.; Gilad, S.; Rotman, G.; Ziv, Y.; Vanagaite, L.; Tagle, D.A.; Smith, S.; Uziel, T.; Sfez, S. A single ataxia telangiectasia gene with a product similar to PI-3 kinase. Science 1995, 268, 1749-1753. [CrossRef] [PubMed]

114. Metcalfe, J.A.; Parkhill, J.; Campbell, L.; Stacey, M.; Biggs, P.; Byrd, P.J.; Taylor, A.M.R. Accelerated telomere shortening in ataxia telangiectasia. Nat. Genet. 1996, 13, 350-353. [CrossRef] [PubMed]

115. Vaziri, H.; Schächter, F.; Uchida, I.; Wei, L.; Zhu, X.; Effros, R.; Cohen, D.; Harley, C. Loss of telomeric DNA during aging of normal and trisomy 21 human lymphocytes. Am. J. Hum. Genet. 1993, 52, 661. [PubMed] 
116. Horvath, S.; Garagnani, P.; Bacalini, M.G.; Pirazzini, C.; Salvioli, S.; Gentilini, D.; Di Blasio, A.M.; Giuliani, C.; Tung, S.; Vinters, H.V. Accelerated epigenetic aging in Down syndrome. Aging Cell 2015, 14, 491-495. [CrossRef]

117. Head, E.; Lott, I.T.; Wilcock, D.M.; Lemere, C.A. Aging in Down syndrome and the development of Alzheimer's disease neuropathology. Curr. Alzheimer Res. 2016, 13, 18-29. [CrossRef]

118. Haycock, P.C.; Heydon, E.E.; Kaptoge, S.; Butterworth, A.S.; Thompson, A.; Willeit, P. Leucocyte telomere length and risk of cardiovascular disease: Systematic review and meta-analysis. BMJ 2014, 349, g4227. [CrossRef]

119. Fitzpatrick, A.L.; Kronmal, R.A.; Gardner, J.P.; Psaty, B.M.; Jenny, N.S.; Tracy, R.P.; Walston, J.; Kimura, M.; Aviv, A. Leukocyte telomere length and cardiovascular disease in the cardiovascular health study. Am. J. Epidemiol. 2007, 165, 14-21. [CrossRef]

120. Salpea, K.D.; Humphries, S.E. Telomere length in atherosclerosis and diabetes. Atherosclerosis 2010, $209,35$. [CrossRef]

121. Samani, N.J.; Boultby, R.; Butler, R.; Thompson, J.R.; Goodall, A.H. Telomere shortening in atherosclerosis. Lancet 2001, 358, 472-473. [CrossRef]

122. Minamino, T.; Miyauchi, H.; Yoshida, T.; Ishida, Y.; Yoshida, H.; Komuro, I. Endothelial cell senescence in human atherosclerosis role of telomere in endothelial dysfunction. Circulation 2002, 105, 1541-1544. [CrossRef] [PubMed]

123. Okuda, K.; Khan, M.Y.; Skurnick, J.; Kimura, M.; Aviv, H.; Aviv, A. Telomere attrition of the human abdominal aorta: Relationships with age and atherosclerosis. Atherosclerosis 2000, 152, 391-398. [CrossRef]

124. Aviv, A.; Aviv, H. Telomeres and essential hypertension. Am. J. Hypertens. 1999, 12, 427-432. [CrossRef]

125. Von Zglinicki, T.; Serra, V.; Lorenz, M.; Saretzki, G.; Lenzen-Gro, R.; Geßner, R.; Risch, A.; Steinhagen-Thiessen, E. Short telomeres in patients with vascular dementia: An indicator of low antioxidative capacity and a possible risk factor? Lab. Investig. 2000, 80, 1739-1747. [CrossRef] [PubMed]

126. Wang, Y.Y.; Chen, A.F.; Wang, H.Z.; Xie, L.Y.; Sui, K.X.; Zhang, Q.Y. Association of shorter mean telomere length with large artery stiffness in patients with coronary heart disease. Aging Male 2011, 14, $27-32$. [CrossRef] [PubMed]

127. Cawthon, R.M.; Smith, K.R.; O’Brien, E.; Sivatchenko, A.; Kerber, R.A. Association between telomere length in blood and mortality in people aged 60 years or older. Lancet 2003, 361, 393-395. [CrossRef]

128. Fitzpatrick, A.L.; Kronmal, R.A.; Kimura, M.; Gardner, J.P.; Psaty, B.M.; Jenny, N.S.; Tracy, R.P.; Hardikar, S.; Aviv, A. Leukocyte telomere length and mortality in the Cardiovascular Health Study. J. Gerontol. A Biol. Sci. Med. Sci. 2011, 66, 421-429. [CrossRef]

129. Epel, E.S.; Merkin, S.S.; Cawthon, R.; Blackburn, E.H.; Adler, N.E.; Pletcher, M.J.; Seeman, T.E. The rate of leukocyte telomere shortening predicts mortality from cardiovascular disease in elderly men. Aging 2009, 1, 81. [CrossRef]

130. Jeanclos, E.; Krolewski, A.; Skurnick, J.; Kimura, M.; Aviv, H.; Warram, J.H.; Aviv, A. Shortened telomere length in white blood cells of patients with IDDM. Diabetes 1998, 47, 482-486. [CrossRef]

131. Salpea, K.D.; Talmud, P.J.; Cooper, J.A.; Maubaret, C.G.; Stephens, J.W.; Abelak, K.; Humphries, S.E. Association of telomere length with type 2 diabetes, oxidative stress and UCP2 gene variation. Atherosclerosis 2010, 209, 42-50. [CrossRef] [PubMed]

132. Willeit, P.; Raschenberger, J.; Heydon, E.E.; Tsimikas, S.; Haun, M.; Mayr, A.; Weger, S.; Witztum, J.L.; Butterworth, A.S.; Willeit, J. Leucocyte telomere length and risk of type 2 diabetes mellitus: New prospective cohort study and literature-based meta-analysis. PLoS ONE 2014, 9, e112483. [CrossRef] [PubMed]

133. Nai-chieh, Y.; Chen, B.H.; Song, Y.; Lu, X.; Chen, Y.; Manson, J.E.; Kang, M.; Howard, B.V.; Margolis, K.L.; Curb, J.D. A prospective study of leukocyte telomere length and risk of type 2 diabetes in postmenopausal women. Diabetes 2012. [CrossRef]

134. Zhao, J.; Miao, K.; Wang, H.; Ding, H.; Wang, D.W. Association between telomere length and type 2 diabetes mellitus: A meta-analysis. PLoS ONE 2013, 8, e79993. [CrossRef] [PubMed]

135. Thomas, P.; O'Callaghan, N.J.; Fenech, M. Telomere length in white blood cells, buccal cells and brain tissue and its variation with ageing and Alzheimer's disease. Mech. Ageing Dev. 2008, 129, 183-190. [CrossRef] [PubMed] 
136. Panossian, L.; Porter, V.; Valenzuela, H.; Zhu, X.; Reback, E.; Masterman, D.; Cummings, J.; Effros, R. Telomere shortening in T cells correlates with Alzheimer's disease status. Neurobiol. Aging 2003, 24, 77-84. [CrossRef]

137. Honig, L.S.; Schupf, N.; Lee, J.H.; Tang, M.X.; Mayeux, R. Shorter telomeres are associated with mortality in those with APOE $€ 4$ and dementia. Ann. Neurol. 2006, 60, 181-187. [CrossRef]

138. Grodstein, F.; van Oijen, M.; Irizarry, M.C.; Rosas, H.D.; Hyman, B.T.; Growdon, J.H.; De Vivo, I. Shorter telomeres may mark early risk of dementia: Preliminary analysis of 62 participants from the nurses' health study. PLoS ONE 2008, 3, e1590. [CrossRef]

139. Martin-Ruiz, C.; Dickinson, H.O.; Keys, B.; Rowan, E.; Kenny, R.A.; Von Zglinicki, T. Telomere length predicts poststroke mortality, dementia, and cognitive decline. Ann. Neurol. 2006, 60, 174-180. [CrossRef]

140. Hochstrasser, T.; Marksteiner, J.; Humpel, C. Telomere length is age-dependent and reduced in monocytes of Alzheimer patients. Exp. Gerontol. 2012, 47, 160-163. [CrossRef]

141. Valdes, A.; Deary, I.; Gardner, J.; Kimura, M.; Lu, X.; Spector, T.; Aviv, A.; Cherkas, L. Leukocyte telomere length is associated with cognitive performance in healthy women. Neurobiol. Aging 2010, 31, 986-992. [CrossRef] [PubMed]

142. Zekry, D.; Herrmann, F.R.; Irminger-Finger, I.; Ortolan, L.; Genet, C.; Vitale, A.-M.; Michel, J.-P.; Gold, G.; Krause, K.-H. Telomere length is not predictive of dementia or MCI conversion in the oldest old. Neurobiol. Aging 2010, 31, 719-720. [CrossRef]

143. Watfa, G.; Dragonas, C.; Brosche, T.; Dittrich, R.; Sieber, C.; Alecu, C.; Benetos, A.; Nzietchueng, R. Study of telomere length and different markers of oxidative stress in patients with Parkinson's disease. J. Nutr. Health Aging 2011, 15, 277-281. [CrossRef] [PubMed]

144. Guan, J.Z.; Maeda, T.; Sugano, M.; Oyama, J.-I.; Higuchi, Y.; Suzuki, T.; Makino, N. A percentage analysis of the telomere length in Parkinson's disease patients. J. Gerontol. A Biol. Sci. Med. Sci. 2008, 63, 467-473. [CrossRef] [PubMed]

145. Wang, H.; Chen, H.; Gao, X.; McGrath, M.; Deer, D.; De Vivo, I.; Schwarzschild, M.A.; Ascherio, A. Telomere length and risk of Parkinson's disease. Mov. Disord. 2008, 23, 302-305. [CrossRef]

146. Torre, L.A.; Siegel, R.L.; Ward, E.M.; Jemal, A. Global cancer incidence and mortality rates and trends-An update. Cancer Epidemiol. Biomark. Prev. 2016, 25, 16-27. [CrossRef] [PubMed]

147. Campisi, J.; Andersen, J.K.; Kapahi, P.; Melov, S. Cellular senescence: A link between cancer and age-related degenerative disease? Proce. Semin. Cancer Biol. 2011, 21, 354-359. [CrossRef]

148. Wright, W.E.; Pereira-Smith, O.; Shay, J. Reversible cellular senescence: Implications for immortalization of normal human diploid fibroblasts. Mol. Cell. Biol. 1989, 9, 3088-3092. [CrossRef]

149. Oh, B.-K.; Kim, Y.-J.; Park, C.; Park, Y.N. Up-regulation of telomere-binding proteins, TRF1, TRF2, and TIN2 is related to telomere shortening during human multistep hepatocarcinogenesis. Am. J. Pathol. 2005, 166, 73-80. [CrossRef]

150. De Lange, T. Telomere-related genome instability in cancer. Cold Spring Harb. Symp. Quant. Biol. 2005, 70, 197-204. [CrossRef]

151. Cheung, A.; Deng, W. Telomere dysfunction, genome instability and cancer. Front. Biosci. 2008, 13, $2075-2090$. [CrossRef] [PubMed]

152. Nowell, P.C. Genetic alterations in leukemias and lymphomas: Impressive progress and continuing complexity. Cancer Genet. Cytogenet. 1997, 94, 13-19. [CrossRef]

153. Albertson, D.G.; Collins, C.; McCormick, F.; Gray, J.W. Chromosome aberrations in solid tumors. Nat. Genet. 2003, 34, 369. [CrossRef] [PubMed]

154. Wright, W.E.; Shay, J.W. The two-stage mechanism controlling cellular senescence and immortalization. Exp. Gerontol. 1992, 27, 383-389. [CrossRef]

155. Jafri, M.A.; Ansari, S.A.; Alqahtani, M.H.; Shay, J.W. Roles of telomeres and telomerase in cancer, and advances in telomerase-targeted therapies. Genome Med. 2016, 8, 69. [CrossRef] [PubMed]

156. Heaphy, C.M.; Subhawong, A.P.; Hong, S.-M.; Goggins, M.G.; Montgomery, E.A.; Gabrielson, E.; Netto, G.J.; Epstein, J.I.; Lotan, T.L.; Westra, W.H. Prevalence of the alternative lengthening of telomeres telomere maintenance mechanism in human cancer subtypes. Am. J. Pathol. 2011, 179, 1608-1615. [CrossRef] [PubMed] 
157. Deng, W.; Tsao, S.W.; Guan, X.Y.; Lucas, J.N.; Cheung, A.L. Role of short telomeres in inducing preferential chromosomal aberrations in human ovarian surface epithelial cells: A combined telomere quantitative fluorescence in situ hybridization and whole-chromosome painting study. Genes Chromosomes Cancer 2003, 37, 92-97. [CrossRef]

158. Der-Sarkissian, H.; Bacchetti, S.; Cazes, L.; Londoño-Vallejo, J.A. The shortest telomeres drive karyotype evolution in transformed cells. Oncogene 2004, 23, 1221-1228. [CrossRef]

159. Chevret, E.; Andrique, L.; Prochazkova-Carlotti, M.; Ferrer, J.; Cappellen, D.; Laharanne, E.; Idrissi, Y.; Boettiger, A.; Sahraoui, W.; Ruiz, F. Telomerase functions beyond telomere maintenance in primary cutaneous T-cell lymphoma. Blood 2014. [CrossRef]

160. Wentzensen, I.M.; Mirabello, L.; Pfeiffer, R.M.; Savage, S.A. The association of telomere length and cancer: A meta-analysis. Cancer Epidemiol. Biomark. Prev. 2011, 20, 1238-1250. [CrossRef]

161. Willeit, P.; Willeit, J.; Mayr, A.; Weger, S.; Oberhollenzer, F.; Brandstätter, A.; Kronenberg, F.; Kiechl, S. Telomere length and risk of incident cancer and cancer mortality. JAMA 2010, 304, 69-75. [CrossRef] [PubMed]

162. Donaires, F.S.; Scatena, N.F.; Alves-Paiva, R.M.; Podlevsky, J.D.; Logeswaran, D.; Santana, B.A.; Teixeira, A.C.; Chen, J.J.-L.; Calado, R.T.; Martinelli, A.L. Telomere biology and telomerase mutations in cirrhotic patients with hepatocellular carcinoma. PLoS ONE 2017, 12, e0183287. [CrossRef] [PubMed]

163. Donati, B.; Pietrelli, A.; Pingitore, P.; Dongiovanni, P.; Caddeo, A.; Walker, L.; Baselli, G.; Pelusi, S.; Rosso, C.; Vanni, E. Telomerase reverse transcriptase germline mutations and hepatocellular carcinoma in patients with nonalcoholic fatty liver disease. Cancer Med. 2017, 6, 1930-1940. [CrossRef] [PubMed]

164. Barthel, F.P.; Wei, W.; Tang, M.; Martinez-Ledesma, E.; Hu, X.; Amin, S.B.; Akdemir, K.C.; Seth, S.; Song, X.; Wang, Q. Systematic analysis of telomere length and somatic alterations in 31 cancer types. Nat. Genet. 2017, 49, 349. [CrossRef] [PubMed]

165. Haycock, P.C.; Burgess, S.; Nounu, A.; Zheng, J.; Okoli, G.N.; Bowden, J.; Wade, K.H.; Timpson, N.J.; Evans, D.M.; Willeit, P. Association between telomere length and risk of cancer and non-neoplastic diseases: A Mendelian randomization study. JAMA Oncol. 2017, 3, 636-651. [CrossRef]

166. Pellatt, A.J.; Wolff, R.K.; Torres-Mejia, G.; John, E.M.; Herrick, J.S.; Lundgreen, A.; Baumgartner, K.B.; Giuliano, A.R.; Hines, L.M.; Fejerman, L. Telomere length, telomere-related genes, and breast cancer risk: The breast cancer health disparities study. Genes Chromosomes Cancer 2013, 52, 595-609. [CrossRef]

167. Sanchez-Espiridion, B.; Chen, M.; Chang, J.Y.; Lu, C.; Chang, D.W.; Roth, J.A.; Wu, X.; Gu, J. Telomere length in peripheral blood leukocytes and lung cancer risk: A large case-control study in Caucasians. Cancer Res. 2014. [CrossRef]

168. Ma, H.; Zhou, Z.; Wei, S.; Liu, Z.; Pooley, K.A.; Dunning, A.M.; Svenson, U.; Roos, G.; Hosgood, H.D., III; Shen, M. Shortened telomere length is associated with increased risk of cancer: A meta-analysis. PLoS ONE 2011, 6, e20466. [CrossRef]

169. Anic, G.M.; Sondak, V.K.; Messina, J.L.; Fenske, N.A.; Zager, J.S.; Cherpelis, B.S.; Lee, J.-H.; Fulp, W.J.; Epling-Burnette, P.K.; Park, J.Y. Telomere length and risk of melanoma, squamous cell carcinoma, and basal cell carcinoma. Cancer Epidemiol. 2013, 37, 434-439. [CrossRef]

170. Pooley, K.A.; Sandhu, M.S.; Tyrer, J.; Shah, M.; Driver, K.E.; Luben, R.N.; Bingham, S.A.; Ponder, B.A.; Pharoah, P.D.; Khaw, K.-T. Telomere length in prospective and retrospective cancer case-control studies. Cancer Res. 2010, 70, 3170-3176. [CrossRef]

171. Tacutu, R.; Craig, T.; Budovsky, A.; Wuttke, D.; Lehmann, G.; Taranukha, D.; Costa, J.; Fraifeld, V.E.; De Magalhães, J.o.P. Human Ageing Genomic Resources: Integrated databases and tools for the biology and genetics of ageing. Nucleic Acids Res. 2012, 41, D1027-D1033. [CrossRef] [PubMed]

172. Dato, S.; Rose, G.; Crocco, P.; Monti, D.; Garagnani, P.; Franceschi, C.; Passarino, G. The genetics of human longevity: An intricacy of genes, environment, culture and microbiome. Mech. Ageing Dev. 2017, 165, 147-155. [CrossRef] [PubMed]

173. Khan, S.S.; Singer, B.D.; Vaughan, D.E. Molecular and physiological manifestations and measurement of aging in humans. Aging Cell 2017, 16, 624-633. [CrossRef] [PubMed]

174. Van de Ven, R.A.; Santos, D.; Haigis, M.C. Mitochondrial sirtuins and molecular mechanisms of aging. Trends Mol. Med. 2017, 23, 320-331. [CrossRef] [PubMed] 
175. Turner, K.J.; Vasu, V.; Greenall, J.; Griffin, D.K. Telomere length analysis and preterm infant health: The importance of assay design in the search for novel biomarkers. Biomark. Med. 2014, 8, 485-498. [CrossRef] [PubMed]

176. Cunningham, J.M.; Johnson, R.A.; Litzelman, K.; Skinner, H.G.; Seo, S.; Engelman, C.D.; Vanderboom, R.J.; Kimmel, G.W.; Gangnon, R.E.; Riegert-Johnson, D.L. Telomere length varies by DNA extraction method: Implications for epidemiologic research. Cancer Epidemiol. Biomark. Prev. 2013. [CrossRef] [PubMed]

177. Zanet, D.L.; Saberi, S.; Oliveira, L.; Sattha, B.; Gadawski, I.; Côté, H.C. Blood and dried blood spot telomere length measurement by qPCR: Assay considerations. PLoS ONE 2013, 8, e57787. [CrossRef]

(C) 2019 by the authors. Licensee MDPI, Basel, Switzerland. This article is an open access article distributed under the terms and conditions of the Creative Commons Attribution (CC BY) license (http://creativecommons.org/licenses/by/4.0/). 